\title{
MENAPAKI JALAN KONSTITUSIONAL MENUJU ZAKEN CABINET : IKHTIAR MEWUJUDKAN PEMERINTAH BERKUALITAS KONSTITUSI
}

\author{
Novendri M. Nggilu, Fence M. Wantu \\ Hukum Tata Negara, Fakultas HukumUniversitas Negeri Gorontalo \\ Jl. Jendral Sudirman No. 6 Kota Gorontalo, 96271 \\ novendrilawfaculty@ung.ac.id, fenceonetwo@yahoo.com
}

\begin{abstract}
The long path of constitutional to find the government format has led to the point of choice of the presidential system with a multi-party system that is confronted with the political reality of the coalition in carrying and winning the presidential candidate. The success of an elected president in carrying out his constitutional duties going forward, one of which will be determined from the success of the president in choosing his ministers, a president who is not strong and brave, will be very vulnerable to being controlled by the support party in the coalition frame, including in terms of appointing the minister, so that it will reduce the president's prerogative rights. The purpose of this paper is to decipher the ideal cabinet fulfillment concept in order to realize a constitutional quality government. The approach used the historical and statute approach with prescriptive analysis techniques. As a result, in legally, the provisions regarding the requirements for appointment of ministers by the president still have an empty space related to the requirements for qualifications, competencies or expertise of a person in the appointment as minister. This condition is not rare causes the appointment of ministers more based on the share of "gift-vouchers" by the president to political parties as an act of returning the favor to the sweat of the party that poured during his election as president. The choice of walking the constitutional path to the zaken cabinet is the right choice, with the appointment mechanism that creates a culture of competition, selective and objective, where all can propose people who are considered good and competent, and a small team formed by the president who will trace the track record of expertise and the candidates expertise and integrity, and the results being the recommendations to the president who will determine who the ministers will help him realize a quality constitutional government, fulfill the constitutional promise at the Opening of the 1945 Constitution of the Republic of Indonesia, as well as fulfilling the constitutional rights of its citizens.
\end{abstract}

\section{Keywords : Presidential, Zaken Cabinet, Constitution}

Abstrak, Jalan panjang konstitusional untuk menemukan format pemerintah telah mengantarkan pada titik pilihan sistem presidensil dengan sistem multi-partai yang diperhadapkan dengan realitas politik koalisi dalam mengusung dan memenangkan kandidat presiden. Keberhasilan seorang presiden terpilih dalam melaksanakan tugas konstitusionalnya ke depan, salah satunya akan ditentukan dari keberhasilan presiden dalam memilik menteri-menterinya, seorang presiden yang tidak kuat dan berani, akan sangat rentan untuk dikendalikan oleh partai pengusung dalam bingkai koalisi, termasuk dalam hal pengangkatan menteri, sehingga akan mengurangi hak prerogatif presiden. Tujuan dari tulisan ini adalah untuk menguraikan konsep zaken kabinet yang ideal dalam rangka mewujudkan pemerintahan yang berkualitas konstitusi. Pendekatan ini menggunakan pendekatan historis dan statuta dengan teknik analisis preskriptif. Secara yuridis, ketentuan mengenai persyaratan pengangkatan menteri oleh presiden masih menimbulkan ruang kosong, terkait dengan persyaratan

$$
\sim 126 \sim
$$


kualifikasi, kompetensi atau keahlian seseorang dalam pengangkatan sebagai menteri. Kondisi ini tidak jarang menyebabkan pengangkatan menteri lebih didasarkan pada pembagian "voucher hadiah" oleh presiden kepada partai politik sebagai balas budi atas keringat yang bercucuran pada saat pemenangannya sebagai presiden. Pilihan jalan konstitusional zaken kabinet adalah pilihan yang tepat, dengan mekanisme yang menciptakan budaya kompetisi, selektif, dan objektif, di mana semua dapat mengusulkan orang-orang yang dianggap baik dan kompeten, dan tim kecil bentukan presiden yang akan menelusuri rekam jejak keahlian kandidat serta intergritasnya, dan hasilnya menjadi rekomendasi kepada presiden yang akan menentukan siapa menteri yang akan membantunya mewujudkan pemerintahan berkualitas konstitusi, memenuhi janji konstitusional pada Pembukaan UUD1945 serta memenuhi hak konstitusional warga negara.

Kata Kunci : Presidensil; Kabinet Zaken; Konstitusi.

\section{Pendahuluan}

Sebagai konsekuensi dari negara demokrasi konstitusional, maka konstitusi sejatinya harus memuat aspek yang bersifat fundamental, meliputi pengaturan mengenai jaminan terhadap hak asasi manusia dari warga negaranya, ditetapkannya ketatanegaraan suatu negara yang bersifat fundamental, serta adany apembagian dan pembatasan tugas ketatanegaraan yang juga bersifat fundamental. ${ }^{1}$ Aspek ketatanegaraan yang diatur dalam konstitusi salah satunya adalah pengaturan tentang lembaga-lembaga negara utama, satu di antaranya adalah lembaga kepresidenan yang dipimpin oleh presiden hasil dari kontestasi pemilihan presiden dan wakil presiden.

Di setiap helatan pemilihan presiden sebagai ekspresi pesta demokrasi selalu saja diwarnai keriuhan tentang pengisian cabinet kerja oleh presiden terpilih. Presiden terpilih yang merdeka, akan senantiasa tenang dan nyaman dalam menentukan pengisian jabatan Menteri dalam kabinetnya, namun berbeda halnya manakala presiden terpilih berada di bawah bayang-bayang koalisi pemenangan, sudah dapat dipastikan bahwa hak prerogative presiden dalam menentukan menteri dalam kabinetnya akan tereduksi oleh desakan, intervensi dan bahkan rasa balas budi terhadap partai koalisi yang memenangkannya.

Jika bercermin terhadap konstitusi, presiden memiliki tanggung jawab yang tidaklah ringan, presiden dituntut untuk mewujudkan apa yang menjadi rechtidee sebagaimana tertuang dalam Pembukaan Undang-Undang Dasar Tahun 1945 (UUD 1945) meliputi "melindungi segenap bangsa Indonesia dan seluruh tumpah darah Indonesia dan untuk memajukan kesejahteraan umum, mencerdaskan kehidupan bangsa, dan ikut melaksanakan ketertiban dunia". Oleh karena tanggungjawab dan tugasnya tidaklah ringan, presiden diberikan kewenangan absolute dalam mengangkat dan memberhentikan menteri-menteri negara yang sifatnya auxiliary.

\footnotetext{
${ }^{1}$ Novendri M. Nggilu., Hukum dan Teori Konstitusi (Perubahan Konstitusi yang Partisipatif dan Populis), (Yogyakarta : UII Pres. 2014), hlm. 28.
} 
Secara konstitusional, menteri yang merupakan pembantu presiden membidangi urusan tertentu dalam pemerintahan yang esensinya membantu presiden guna mewujudkan tujuan sebagaimana dimaksud dalam pembukaan konstitusi Indonesia sertaapa yang menjadi visimisi dari presiden dan wakil presiden. Oleh sebab itu, pengisian menteri tersebut harus mempertimbangkan kepakaran, keahlian dari menteri yang diangkat.

Jika menarik konteks diskursus mengenai pengangkatan menteri dengan pilihan ketetatanegaraan yaitu system presidensil yang dielaborasi dengan sistem multi partai, memang memiliki catatan dan potensi persoalan yang akan mewarnai pelaksanaannya. Linz misalnya melihat pilihan system presidensial sering memunculkan persoalan yang disebut dengan istilah "the perils of presidensidentialism". Paling tidak ada tiga masalah bawaan yang ditimbulkan oleh system presidensial ini : pertama, dual legitimacy, proses pengisian kursi legislative dan presiden yang sama-sama menggunakan system pemilihan langsung oleh rakyat, menjadikan kedua centrum kekuasaan ini memiliki legitimasi yang sama kuat, manakala terjadi konflik di antara kedua Lembaga ini, maka kemungkinan yang terjadi adalah kebuntuan. Kedua, rigidity, yaitu kedua centrum kekuasaan ini memiliki masa jabatan yang tetap (kecuali ada alasan tertentu sehingga terjadi impeachment), maka bilaada ketidakpuasan terhadap presiden, tidak ada jalan lain kecuali menunggu hingga berakhirnya masa jabatan presiden. Ketiga, majoritarian tendency, yaitu ketika seorang presiden memiliki kecenderungan mengabaikan legislative (imperial president), atau ketika presiden merasa menghadapi legislative yang tidak bersahabat (misalnya dikuasai oleh oposisi/ divided government), maka dia dapat atau akan mencari celah-celah memperluas kekuasaannya. Ini dapat berujung pada makin lemahnya legislatif dan rejim politik menjadi otoritarian. Kondisi inilah menurut Linz sangat potensial menyebabkan kejatuhan demokrasi(democratic breakdown). ${ }^{2}$

Kondisi di atas menjadi lebih problematic mana kala system presidensial "dikawinkan" dengan sistem multi partai, ${ }^{3}$ menurut Main waring, Shugart dan Carey, system presidensial multi partai ini, presiden terpilih cenderung tidak memiliki dukungan mayoritas di legislatif. Banyaknya partai yang ikut pemilu membuat sangat sulit bagi satu partai untuk memenangkan pemilu secara mayoritas. Ini akan berujung pada minoritasnya dukungan presiden di legislatif, sekalipun partainya adalah pemenang pemilu. Kondisi inilah yang menyebabkan pilihan untuk berkoalisi menjadi pilihan utama. ${ }^{4}$

Kondisi tersebut di atas juga menimpa Indonesia, bahkan kondisi tersebut sedikit diperparah dengan adanya persyaratan presidential threshold yang menyebabkan sulit suatu

${ }^{2}$ Djayadi Hanan, Memperkuat Presidensialisme Multipartai di Indonesia: Pemilu Serentak, Sistem Pemilu, dan Sistem Kepartaian, Pusat Kajian Politik Universitas Indonesia, 12 Februari 2015, hlm. 1, https://www.puskapol.ui.ac.id/publikasi_puskapol/memperkuat-presidensialisme-multipartaidi-indonesia-pemilu-serentak-sistem-pemilu-dan-sistem-kepartaian.html, diakses pada 5 Agustus 2019, pukul 17.35

${ }^{3}$ Retno Saraswati, Desain Sistem Presidensial Yang Efektif, Jurnal MMH, Jilid 41 Nomor 1 Januari 2012, hlm. 137

${ }^{4}$ Ibid., hlm. 2 
partai mencalonkan presiden dan wakil presidennya secara mandiri, tegasnya pilihan untuk berkoalisi adalah pilihan satu-satunya. Dalam proses koalisi itulah, kompromi politik akan senantiasa mewarnai diskursus dukungan dan pemenangan, yang ujungnya akan menemukan satu titik, dimana tidak ada dukungan yang gratis, artinya salah satu bentuk balas budi calon presiden dan wakil presiden terpilih kepada partai politik yang memenangkannya adalah penjatahan pengisian kursi menteri dalam kabinetnya.

Desakan mengenai zaken kabinet pada pemerintahan Joko Widodo memang tercermin melalui komposisi para profesional yang banyak mengisi post kabinet Menteri, akan tetapi proses bagi-bagi kue kekuasaan dikemas lebih halus dengan cara melakukan pembentukan pos-pos jabatan baru yaitu melalui pos jabatan wakil Menteri.

Tulisan ini menjadi penting untuk menguraikan zaken cabinet sebagai bagian dari ikhtiar menjaga perjuangan para pembentuk negara, sekaligus menjaga marwah konstitusi melalui penempatan pos-pos jabatan-jabatan strategis khususnya jabatan Menteri dari kalangan profesional agar dapat mewujudkan apa yang menjadicita-cita negara.

Realitas politik Indonesia hari-hari ini menunjukkan bahwa pengisian jabatan menteri negara sangat kental kaitannya dengan aspek bagi-bagi "kue" untuk koalisi yang telah berkeringat memenangkan presiden dan wakil presiden. Oleh sebab itu, tulisan ini hendak menjawab pertanyaan tentang konsep pengisian cabinet seperti apa yang ideal guna mewujudkan pemerintahan yang berkualitas konstitusi.

\section{Metode Pendekatan}

Pendekatan yang akan digunakan dalam penelitian ini adalah pendekatan historis untuk menggambarkan kabinet yang diidentikan sebagai zaken kabinet pada era Soekarno, termasuk gagasan yang sempat mengemuka pada saat Perubahan UUD 1945 yang berlangsung pada tahun 1999-2002 khusunya berkaitan dengan gagasan pengangkatan Menteri sebagaimana tertuang dalam Pasal 17 UUD NRI Tahun 1945. Pendekatan yang kedua adalah pendekatan statute dengan cara menarik garis hirarkis dalam UUD khususnya Pasal 17 hingga keperaturan perundang-undangan lainnya utamanya Undang-Undang Nomor 39 Tahun 2008 tentang Kementerian Negara. Bahan hukum yang diperoleh kemudian akan dianalisis menggunakan teknis preskriptif.

\section{Hasil Penelitian dan Pembahasan}

\section{Potret Kabinet Zaken Di Era Soekarno dan Pasca Reformasi}

Jika menyusuri jejak sejarah Indonesia, pembahasan dan pengaturan mengenai kekuasaan pemerintah sejatinya telah muncul sejak pembahasan pada Badan Penyelidik Usaha Persiapan Kemerdekaan Indonesia (BPUPKI) termasuk isu mengenai menteri, hanya saja pada saat itu, isu terkait soal Menteri sangatlah erat kaitannya dengan system pemerintahan yang hendak dipilih, ada yang menghendaki bahwa pemimpin negara adalah seorang maharaja, ada yang menginginkan negara dipimpin oleh seorang pemimpin besar, 
dan ada pula yang menginginkan negara dipimpin oleh seorang presiden dan dibentuk oleh perdana menteri. ${ }^{5}$

Dalam desain konstitusional di awal negara terbentuk hingga sekarang, kementerian ditempatkan sebagai alat negara yang dimaknai secara integral dalam pemerintah bersamaan dengan presiden yang fungsinya sebagai auxiliary terhadap pelaksanaan tugas dan kewenangan presiden. Pertimbangan itulah yang kemudian menempatkan kewenangan pengangkatan dan pemberhentian menteri menjadi hak prerogative dari presiden, meski kemudian di awal negara ini dibentuk mekanisme pembentukannya dilakukan oleh seseorang atau beberapa orang yang ditunjuk oleh presiden untuk membentuk kabinet. ${ }^{6}$

Zaken cabinet sejatinya merupakan cabinet ahli ${ }^{7}$, atau juga dikenal dengan istilah bussines cabinet ${ }^{8}$ yang dimaknai kabinet yang diisi oleh professional dan ahli pada urusan yang dibidangi. Jejak sejarah cabinet zaken sejatinya sering kali dikaitkan dengan cabinet Natsir tahun 1950, dimana cabinet ini memiliki program meliputi : (a) menyelenggarakan pemilihan umum untuk konstituante dalam waktu singkat; (b) mencapai konsolidasi dan menyempurnakan susunan pemerintahan; (c) menggiatkan usaha mencapai keamanan dan ketenteraman; (d) memperkembangkan dan memperkokoh kekuatan ekonomi nasional yang sehat; (e) membantu pembangunan perumahan rakyat serta memperluas usaha-usaha meninggikan derajat kesehatan dan kecerdasan rakyat; (f) menyempurnakan organisasi angkatan perang dan pemulihan bekas-bekas anggota tantara dan gerilya ke dalam masyarakat; (g) memperjuangkan penyelesaian soal Irian Barat dalam tahun ini. ${ }^{9}$

Kabinet Natsir disebut sebagai cabinet zaken disebabkan oleh orang-orang yang menempati posisi menteri diisi oleh orang yang professional dan ahli, di antaranya ahli ekonomi dan keuangan terkemuka pada waktu itu yakni Sjafruddin Prawiranegara sebagai Menteri Keuangan dan Soemitro Djojohadikusumo sebagai Menteri Perdagangan dan Perindustrian. Kabinet ini dinilai berhasil disebabkan dapat meningkatkan devisa negara yang pada waktu itu dilatar belakangi terjadinya perang Korea yang berakibat barang-barang ekspor Indonesia mendapat pasaran yang baik di dunia, sehingga kemampuan pemerintah meningkat dalam hal mengendalikan inflasi dengan cara liberalisasi system impor, serta mengandalkan perbaikan-perbaikan yang substansial bagi kondisi ekonomi negara secara menyeluruh, bahkan menurut Yahya Muhaimin, cabinet Natsir merupakan kabinet yang paling jelas konsep-konsep ekonomi dan pembangunannya. Pada cabinet ini pula titik awal

\footnotetext{
${ }^{5}$ Mahkamah Konstitusi. Naskah Komprehensif Buku IV Jilid 1 Kekuasaan Pemerintahan Negara, (Jakarta : Sekretarian jenderal Mahkamah Konstitusi. 2010). hlm. 11

${ }^{6}$ Pasal 51 ayat (1) Undang-Undang Dasar SementaraRepublik Indonesia

${ }^{7}$ Zainal Arifin Mochtar. Kabinet, Koalisi dan Sistem Presidensial, Rapat Kerja Nasional Asosiasi Pengajar Hukum Tata Negara dan Hukum Administrasi Negara, Gorontalo, 6 Juli 2019. hlm. 5

${ }^{8}$ Remy Madinier, Islam and Politics in Indonesia : The Masyumi Party between Democracy and Integralism, (Singapore : National University of Singapore, 2015), hlm. 125

${ }^{9}$ Sardiman, Sejarah : Program Ilmu Sosial, (Jakarta : Quadra. 2006), hlm. 115. 
terbentuknya Biro Perancang Nasional $(\mathrm{BPN})^{10}$ yang kemudian berkembang menjadi Badan Perencanaan Pembangunan Nasional (Bappenas) yang sangat berperan dalam pembangunan Indonesia. ${ }^{11}$

Kabinet Natsir juga berhasil berperan dalam politik luar negeri, salah satu diantaranya adalah gagasan mengenai gerakan non blok pada Inter Asia Conference ke-3 di New Delhi pada 1950 yang disebutnya dengan "third power policy". Meski usulannya pada waktu itu tidak terakomodir, gagasan inilah yang kemudian memantik pembentukan gerakan non blok pada forum Konfrensi Asia Afrika di Bandung tahun 1955. Pada masa Kabinet Natsir pulalah kemudian Indonesia menjadi anggota Perserikatan Bangsa-Bangsa yang ke-60. ${ }^{12}$ Dalam hal hubungan antara militer, Kabinet Natsir juga dinilai memiliki hubungan yang baik, bahkan berhasil bekerjasama dengan pihak militer dalam meredam gerakan RMS, menyelesaikan persoalan Aceh. ${ }^{13}$ Di samping itu juga, Kabinet Natsir berperan dalam membuka jalan penyelesaian kasus Iran Barat dengan cara pembubaran Uni Indonesia-Belanda serta mengembalikan kembali Irian Barat kepangkuan Ibu Pertiwi. ${ }^{14}$

Kabinet yang diidentikan dengan zaken cabinet ini kemudian mengalami turbulensi politik sejak terjadinya ketegangan soal cara untuk membubar kan uni Indonesia-Belanda disebabkan adanya ketersinggungan Presiden Soekarno, karena Natsir meminta persoalan kesepakatan pembubaran Uni Indonesia-Belanda diserahkan pada cabinet melalui pembahasan dalam rapat kabinet, yang hal ini merupakan kesepakatan mereka berdua diawal pembentukan Kabinet Natsir, dimana soal-soal politik penting, hak pengambilan keputusan ada di tangan cabinet dengan persetujuan parlemen. ${ }^{15}$ Hal ini diperparah dengan penarikan menteri-menteri dari perwakilan partai dalam parlemen yang kemudian menjadi krisis politik di cabinet Natsir hingga akhirnya Natsir mengembalikan mandatnya kepada Soekarno.

Meskipun cabinet Natsir terhitung singkat, hanya berusia 8 (delapan) bulan (sejak 6 September 1950 sampai 27 April 1951), namun menurut Herbert Feith seorang Profesor di Monash University cabinet Natsir telah berusaha mencapai tujuan politiknya dengan sungguh-sungguh dan hasilnya yang cukup penting meliputi aspek keamanan, penertiban administrasi, peningkatan produksi dan pengembangan ekonomi yang terencana. ${ }^{16}$

Selain cabinet Natsir, yang juga dinilai identik dengan Kabinet Zaken, adalah Kabinet Wilopo. Kabinet Wilopo dibentuk pada 3 April tahun 1952 hingga 30 Juli 1953. Kabinet ini diidentikan dengan Zaken Kabinet dikarenakan postur kabinetnya juga diisi oleh kalangan

${ }^{10}$ Lembaga ini terbentuk dengan didahului oleh langkah Kabinet Natsir yang menugaskan sebuah perusahaan riset dari Amerika Serikat J.C. White engineering Corp untuk melakukan studi kelayakan bagi pembentukan Biro Perancang Nasional.

${ }^{11}$ M Dzulfikriddin. Natsir Dalam Sejarah Politik Indonesia : Peran dan Jasa Mohammad Natsir Dalam Dua Orde Indonesia, (Bandung : Mizan pustaka, 2010). hlm. 69

${ }^{12}$ Ibid., hlm. 68

${ }^{13}$ Ibid., hlm. 65

${ }^{14}$ Ibid., hlm. 71

${ }^{15}$ Ibid., hlm. 72

${ }^{16}$ Ibid., hal. 76 
ahli dan professional, di antaranya Djuanda yang juga merupakan menteri non partisan dengan jabatan sebagai Menteri Perhubungan serta Bahder Djohan yang merupakan menteri non partisan menjabat sebagai Menteri Pendidikan dan Kebudayaan, bahkan menurut Herbert Feith, sebuah cabinet Wilopo merupakan kabinet yang mempertimbangkan komposisi yang sesuai, artinya ketimbang menggantungkan diri kepada partai dan parlemen, cabinet ini diisi oleh orang-orang yang sama-sama memiliki kapasitas dan dapat bekerjasama denganbaik. ${ }^{17}$ Kabinet ini mengupayakan tercapainya 5 (lima) program yaitu melaksanakan pemilihan umum, meningkatkan kemakmuranrakyat, menciptakan keamanan dalam negeri, memperjuangkan Irian Barat, dan melaksanakan politik luar negeri bebas aktif, namun cabinet ini kemudian tidak mampu bertahan di tengah badai stabilitas pemerintahan, kemanan dan politik ketika itu, yang kemudian berujung pada runtuhnya kabinet ini.

Pada tahun 1957, Presiden Soekarno mengeluarkan Keputusan Presiden Nomor 46 Tahun 1957 yang dalam keputusan tersebut menyatakan dengan tegas pembentukan cabinet zaken. Dalam keputusan presiden tersebut, Soekarno menugaskan kepada Suwirjo sebagai formatur untuk membentuk Kabinet Zaken. Soewirjo kemudian diperhadapkan pada situasi politik yang tidak stabil, sebab merupakan oposisi dari Masjumi, Partai Katolik serta partaipartai kecil. Suwirjo kemudian dua kali gagal membentuk kabinet, hingga akhirnya Soekarno membuat keputusan sebagai presiden dengan menunjuk dirinya sebagai warga negara sebagai formatur kabinet. Terlepas dari adanya pertentangan ketika itu, karena presiden menunjuk dirinya sendiri sebagai formatur yang dinilai banyak pihak melanggar ketentuan UndangUndang Dasar, namun kabinet yang dibentuk pada waktu itu juga dinilai sebagai kabinet yang idektik dengan cabinet zaken, dimana menunjuk Djuanda sebagai perdana menteri yang merupakan professional dan non partisan. ${ }^{18}$

Kabinet yang dipimpin oleh Ir. Djuanda Kartawidjadja yang didampingi oleh Hardi, Idham Chalid, dan Leimena ${ }^{19}$ memiliki program kerja yang terdiridari 5 point dan dikenal dengan sebutan Pancakarya, yaitu :

1. Membentuk Dewan Nasional;

2. Normalisasi keadaan Republik Indonesia;

3. Melanjutkan pembatalan KMB;

4. Memperjuangkan Irian Barat kembali ke Republik Indonesia;

5. Mempercepat pembangunan. ${ }^{20}$

${ }^{17}$ Indira Ardanareswari, (2009). KabinetZakenBukantanpaPreseden, Indonesia PernahMemilikinya. Tirto Id, 17 Mei 2019, https:/tirto.id/kabinet-zaken-bukan-tanpa-presedenindonesia-pernah-memilikinya-dJfi, diakses pada 2 Agustus 2019.

${ }^{18}$ BachtiarChamsyah, et.,al., 100 Tahun Mohammad Natsir, Berdamai Dengan Sejarah, (Jakarta : Republika, 2008). hlm. 178.

${ }^{19}$ Ibid., hlm. 179

20 Materikita, (2019). Kabinet Pada Masa Demokrasi Liberal,https://materikita.com/kabinetpada-masa-demokrasi-liberal/, diakses pada 2 Agustus 2019. 
Kabinet Djuanda ini dinilai berhasil, ${ }^{21}$ di antaranya mengatur kembali batas perairan nasional Indonesia, terbentuknya Dewan Nasional sebagai badan bertujuan untuk menampung dan menyalurkan pertumbuhan kekuatan masyarakat dan diketuai oleh presiden, serta diadakannya Muasyawarah Nasional Pembangunan yang bertujuan untuk mengatasi masalah krisis dalam negeri. ${ }^{22}$ Kabinet Djuanda ini kemudian demisioner karena kegagalan Konstituante menyusun Undang-Undang Dasar baru dan keluarnya dekrit Presiden Soekarno tanggal 5 Juli $1959 .^{23}$

Berkaca dari tiga kabinet yang diidentikan dengan cabinet zaken, satu hal yang harus diakui bahwa cabinet tersebut juga tidak biasa melepaskan dirinya dari pusaran kepentingan partai politik, artinya menteri-menteri yang berada di dalamnya juga ada yang merupakan representasi dari partai politik.

Pasca lengsernya Soekarno sebagai presiden dan kemudian digantikan oleh Soeharto, diisi oleh Menteri yang berasal dari professional dan ahli, salah satu yang sangat terkenal adalah B.J Habibe, seorang teknokrat yang juga kemudian melanjutkan tahta kekuasaan kepresidenan di awal reformasi negeri ini digulirkan. Meskipun juga harus diakui bahwa di era Soeharto, era dimana otoritarianisme begitu kuat dan mengental pada pemerintahan ketika itu, termasuk aspek pengangkatan menteri yang sangat kuat dan kental dengan persoalan penjagaan kekuasaan Soeharto sebagai presiden.

Jika kita meloncat dan memotret cabinet pasca lengsernya kekuasaan Soeharto, paling tidak terdapat 6 (enam) kabinet yang diawali oleh Kabinet Reformasi Pembangunan di bawah kepemimpinan Presiden B.J Habibie, kemudian berganti dengan Kabinet Persatuan Nasional di bawah kepempinan Presiden Abdurahman Wahid (Gusdur), yang dilanjutkan oleh Kabinet Gotong Royong di bawah Kepemimpinan Megawaty Soekarno Putri, kemudian berlanjut ke Kebinet Indonesia Bersatu Jilid 1 (satu) di bawah kepemimpinan Susilo Bambang Yudhoyono, dan kemudian berlanjut pada jilid kedua setelah Susilo Bambang Yudhoyono memenangi kontestasi pilres, serta cabinetnya yaitu Kabinet Kerja di bawah kepemimpinan Presiden Joko Widodo.

Dari 6 kabinet tersebut, postur dan komposisi cabinet tersebut tetap sulit melepaskan dirinya dari keterlibatan partai politik atau kalangan politisi dalam cabinet tersebut. Jika kita memulai membaca komposisi menteri pada enam cabinet tersebut, pada cabinet Reformasi Pembangunan di bawah Presiden B.J Habibie, postur cabinet ketika itu diisi oleh 36 orang dengan komposisi 27 dari kalangan professional dan 9 orang menteri dari kalangan politisi, sedangkan postur Kabinet Persatuan Nasional dengan postur 54 orang menteri memiliki komposisi 29 orang dari kalangan professional, akademisi dan non partisan, serta 25 orang dari partai politik. Pasca turbulensi politik yang terjadi ketika itu yang berujung jatuhnya kekuasaan Abdurahman Wahid, cabinet Persatuan Nasional pun kemudian berakhir dan

${ }^{21}$ FebtaPratama Aman, KebijakanPolitikLuar Negeri Indonesia Masa KabinetDjuanda 19571957, Jurnal Socia Volume 10 Nomor 1 Mei 2013. hlm. 80

${ }^{22}$ Materi kita, op.cit.

${ }^{23}$ Febta Pratama Aman, op.cit., hlm. 81 
digantikan dengan Kabinet Gotong Royong dengan postur kabinet 32 orang dengan komposisi 17 profesional, akademisi dan non partisan, serta 15 orang dari kalangan politisi. Di era kepemimpinan Susilo Bambang Yudhoyono (SBY) jilid 1 (satu), dengan nomenklatru Kabinet Indonesia Bersatu memiliki postur kabinet 43 orang dengan komposisi 19 dari kalangan professional, akademisi dan non partisan, serta 24 orang dari kalangan politisi, sedangkan pada jilid kedua, postur kabinetnya menjadi 51 orang menteri dengan komposisi 25 dari kalangan professional, akademisi dan non partisan, sementara 26 lainnya merupakan politisi. Kabinet keenam di bawah kepempinan Joko Widodo dengan Kabinet Kerja memiliki postur kabinet 52 orang dengan komposisi 29 orang dari kalangan professional, akademisi, dan non partisan, sementara dari kalangan politis berjumlah 23 orang. Lengkapnya postur dan komposisi cabinet tersebut dapat digambarkan melalui table di bawah ini :

Tabel 1.

POSTUR DAN KOMPOSISI KABINET ERA REFORMASI

\begin{tabular}{|c|c|c|c|c|c|c|}
\hline No & Nama Kabinet & Presiden & $\begin{array}{c}\text { Independen/ } \\
\text { Profesional }\end{array}$ & Politisi & Jumlah & Prosentasi \\
\hline 1 & $\begin{array}{l}\text { KabinetReformasi } \\
\text { Pembangunan }\end{array}$ & B.J Habibie & 27 & 9 & 36 Orang & $75 \%: 25 \%$ \\
\hline 2 & $\begin{array}{l}\text { KabinetPersatuan } \\
\text { Nasional }\end{array}$ & $\begin{array}{l}\text { Abdurahman } \\
\text { Wahid }\end{array}$ & 29 & 25 & 54 orang & $53,7 \%: 46,3 \%$ \\
\hline 3 & $\begin{array}{l}\text { Kabinet Gotong } \\
\text { Royong }\end{array}$ & Megawaty S. Putri & 17 & 15 & 32 orang & $53,1 \%: 46,9 \%$ \\
\hline 4 & $\begin{array}{l}\text { Kabinet Indonesia } \\
\text { Bersatu }\end{array}$ & S.B. Yudhoyono & 19 & 24 & 43 orang & $44,2 \%: 55,8 \%$ \\
\hline 5 & $\begin{array}{l}\text { Kabinet Indonesia } \\
\text { Bersatu II }\end{array}$ & S.B. Yudhoyono & 25 & 26 & 51 orang & $49 \%: 51 \%$ \\
\hline 6 & KabinetKerja & Joko Widodo & 29 & 23 & 52 Orang & $55,8 \%: 44,2 \%$ \\
\hline
\end{tabular}

Jika merujuk data tersebut di atas, serta jika menggunakan ukuran tentang kabinet yang diidentikan dengan zaken cabinet mana kala dalam kisaran 60-75persen ${ }^{25}$ diisi oleh professional dan ahli, sementara sisanya dari kalngan politisi, maka kabinet yang identik dengan zaken cabinet adalah cabinet reformasi pembangunan, sebab diisi oleh kalangan professional, akademisi dan non partisan dengan prosentasi 75 persen, sementara cabinet lainnya berkisar antara 44-55 persen.

\footnotetext{
${ }^{24}$ https://id.wikipedia.org/wiki/Kabinet_Reformasi_Pembangunan, https://id.wikipedia.org/wiki/Kabinet_Persatuan_Nasional, https://id.wikipedia.org/wiki/Kabinet_Gotong_Royong, https://id.wikipedia.org/wiki/Kabinet_Indonesia_Bersatu, https://id.wikipedia.org/wiki/Kabinet_Indonesia_Bersatu_II, https://id.wikipedia.org/wiki/Kabinet_Kerja, diakses pada 31 Juli 2019, pukul 20.35.

25 Dadan Sutaryana, (2019). PosturKabinet Jokowi, Momentum MewujudkanZakenKabinet, http://rri.co.id/serui/post/editorial/340/editorial/postur_kabinet_jokowi_momentum_mewujudkan_zake n_kabinet.html, diakses pada 1 Agustus 2019, pukul 13.40.
}

$$
\sim 134 \sim
$$




\section{Zaken Kabinet Sebagai Ikhtiar Mewujudkan Pemerintahan Berkualitas Konstitusi}

Di setiap konstitusi yang diberlakukan dapat dipastikan memuat apa yang menjadi cita atau tujuan negara, baik Undang-Undang Dasar, Konstitusi RIS, Undang-Undang Dasar Sementara, Hingga Undang-Undang Dasar 1945 hasil perubahan pada tahun 1999-2002.

Pada konstitusi Konstitusi Republik Indonesia Serikat Misalnya, cita negara yang hendak diwujudkan oleh pemerintahan adalah kebahagiaan kesejahteraan, perdamaian dan kemerdekaan dalam masyarakat dan negara hukum Indonesia yang merdeka dan berdaulat. ${ }^{26}$ Dalam Undang-Undang Dasar Sementara pun corak cita negara hukum yang hendak diwujudkan sama dengan corak cita negara sebagaimana tertuang dalam Konstitusi RIS. $^{27}$ Sementara dalam Undang-Undang Dasar 1945 hasil reformasi konstitusi di tahun 1999-2002, cita negara hukum yang tertuang dalam Konstitusi RIS dan UUDS tersebut mengalami perubahan menjadi melindungi segenap bangsa dan seluruh tumpah darah Indonesia, mencerdaskan kehidupan bangsa, memajukan kesejahteraan umum, dan ikut dalam ketertiban dunia. ${ }^{28}$

Sebuah pemerintahan berkualitas konstitusi manakala pemerintahan tersebut mampu mewujudkan apa yang menjadi cita negara hukum yang tertuang dalam konstitusi negara tersebut, sekaligus pada saat yang sama mampu menjamin dan menunaikan hak-hak asasi manusia dan hak konstitusional warga negaranya. Dalam konsteks konstitusi Indonesia saat ini, maka pemerintahan berkualitas konstitusi dapat dipenuhi apabila :

1. Pemenuhan terhadap perlindungan seluruh warga negaranya baik perlindungan fisik serta psikis melalui perangkat penegakan hukum yang dimiliki oleh negara, baik kepolisian, TNI, kejaksaan dan lain sebagainya. Mampu memenuhi hak setiap orang dalam hal mencerdaskan kehiudpan bangsa, baik distribusi Pendidikan formal dan non formal bukan hanya terpusat pada satu atau beberapa daerah namun mampu menyentuh seluruh wilayah Indonesia tanpa diskriminasi. Mampu menghadirkan kesejahteraan bagi warganya paling tidak berkaitan dengan pemenuhan kebutuhan pokok sandang dan pangan, dan pada saat yang bersamaan juga aktif terlibat dalam upaya menjaga ketertiban dunia. kesemuanya itu adalah bagian dari pemenuhan kewajiban fundamental negara;

2. Pemerintah berkualitas konstitusi harus mampu menunaikan apa yang menjadi constitutional promise yang meliputi hak asasi manusia dan hak konstitusional warga negara yang merupakan hak fundamental warga negara meliputi hak untuk hidup, melanjutkan keturunan, hak untuk memeluk agama dan keyakinan serta aksesibilitas

\footnotetext{
${ }^{26}$ Mukaddimah Konstitusi Republik Indonesia Serikat

${ }^{27}$ Dalam Undang-Undang Dasar Sementara disebutkan bahwa mewujudkan kebahagiaan kesejahteraan, perdamaian dan kemerdekaan dalam masyarakat dan negara hukum Indonesia yang merdeka dan berdaulat

${ }^{28}$ Alinea Pembukaan Undang-Undang Dasar 1945 
terhadap informasi sebagai perwujudan dari prinsip transparasi dan akuntabilitas negara terhadap warga negaranya.

Mewujudkan pemerintahan berkualitas konstitusi sejatinya bukan hal yang mudah, dan membutuhkan keterampilan dan kompetensi mempuni dari pemerintah. Oleh sebab itu, presiden, wakil presiden serta para Menteri sebagai pembantu presiden harus memiliki kualifikasi dan kompetensi untuk mewujudkan apa yang menjadi janji konstitusi yang tertuang dalam UUD 1945.

Jika mencermati desain yuridis Lembaga kementerian sebagaimana tertuang dalam Undang-Undang Nomor 39 Tahun 2008, tegas dalam konsideran mencerminkan nafas filosofisnya bahwa Menteri sebagai pembantu presiden membidangi dan menyelenggarakan urusan tertentu untuk mencapai tujuan negara sebagaimana terkandung dalam Pembukaan UUD 1945. Dalam undang-undang ini pun sejatinya telah memuat persyaratan seorang dapat diangkat menjadi Menteri, di antaranya ; (a) WNI, (b) bertakwa kepada Tuhan Yang Maha Esa, (c) setia kepada Pancasila sebagai dasar negara, UUD NRI Tahun 1945, dan cita-cita proklamasi kemerdekaan, (d) sehat jasmani dan rohani, (e) memiliki integritas dan kepribadian yang baik, (f) tidak pernah dipidana penjara berdasarkan putusan pengadilan yang telah memperoleh kekuatan hokum tetap karena melakukan tindak pidana yang diancam dengan pidana penjara 5 (lima) tahun atau lebih. ${ }^{29}$

Persyaratan tersebut justru kehilangan nafas filosofisnya disebabkan tugas Menteri sebagai pembantu presiden yang membidangi urusan tertentu guna mewujudkan tujuan negara sebagaimana dimaksud dalam Pembukaan UUD 1945 justru tidak mempersyaratkan sama sekali syarat kompetensi dan keahlian seorang calon Menteri. Adanya "ruang kosong" syarat kompetensi dan keahlian dalam pengangkatan Menteri justru menjadi celah bagi presiden dan koalisinya memandang kursi Menteri sebagai penjatahan atas balas budi keringat pemenangan pada kontestasi pemilihan presiden.

Jika kita sedikit menelisik perdebatan perumusan pasal dalam perubahan undangundang dasar pada tahun 1999-2002, mengemukan persoalan pengisian jabatan Menteri yang merupakan pembantu presiden, dimana gagasan yang muncul berkaitan dengan proses pengisian yang selektif dan kompetitif sehingga menghasilkan Menteri yang memiliki kualitas dan kompetensi yang mempuni, paling tidak gagasan itu tercermin dari pernyataan Rismawan Imawan sebagai berikut $;^{30}$

...yang kami usulkan adalah recruitmentnya yaitu cara mengisi menterinya, bukan menunjuk kepada mekanisme kerjanya. Jadi bagaimana mengisinya, cara mengusulkan ini pak, bias sangat subyektif, bukan rahasia lagi banyak Menteri-menteri yang sebenarnya tidak cocok menempati posisinya...

${ }^{29}$ Pasal 22 Undang-Undang Nomor 39 Tahun 2002 tentang Kementerian Negara.

${ }^{30}$ Mahkamah Konstitusi, Naskah Komprehensif Buku IV Jilid 2 Kekuasaan Pemerintahan Negara, (Jakarta : Sekretarian Jenderal Mahkamah Konstitusi, 2010). hlm. 1051. 
Lebih lanjut Riswandi menyatakan bahwa ${ }^{31}$...menjamin adanya kualifikasi kualitas dan akuntabilitas menteri, sehingga otomatis menjamin pula kualitas dan akuntabilitas kabinet, jadi Presiden tidak hanya bias melihat karena kedekatannya secara pribadi... Perdebatan yang terjadi pada perumusan pasal mengenai kementerian ini memang erat kaitannya dengan keinginan untuk proses pengisian jabatan Menteri harus meminta pertimbangan dari DPR, atau bahkan persetujuan, akan tetapi terlepas dari itu, dalam perumusan pasal mengenai kementerian ada gagasan untuk memunculkan proses yang selektif, ${ }^{32}$ kompetitif $^{33}$ sehingga menghasilkan Menteri yang ahli dan professional.

Menatap kabinet yang akan datang, dorongan untuk membentuk cabinet zaken menjadi sangat penting. Sudah saatnya kabinet yang akan dibentuk akan diisi oleh orang-orang ahli, professional sekaligus memiliki integritas tanpa keraguan. Presiden semestinya dalam mengisi kursi jabatan Menteri harus mempertimbangkan beberapa hal :

1. Memperhatikan rekam jejak calon Menteri dari sisi keahlian dan kapasitasnya. Keahlian dapat saja dilihat melalui riwayat Pendidikan dari calon Menteri serta pengalaman kerja dari sang calom Menteri. Penentuan pengisian seorang pada posisi Menteri sudah semestinya memiliki relevansi antara pengalaman, atau bahkan riwayat pendidikannya denganjabatan Menteri yang akan ditempati. Memang harus diakui bahwa ketentuan Pasal 22 UU No. 39 tahun 2008 tidak mengatur secara ekplisit persyaratan kualifikasi, kompetensi dalam pengangkatan Menteri, "ruang kosong" itulah yang semestinya dapat diisi oleh presiden melalui peraturan presiden terkait pembentukan cabinet atau bahkan langsung dapat dijadikan sebagai ukuran mutlak dalam pengangkatan Menteri yang akan membantu presiden dalam mewujudkan janji konstitusi yang bersifat leerplicht tersebut;

2. Memiliki integritas dan kepribadian yang baik. Syarat pengangkatan Menteri telah megatur secara tegas dan rigid mengenai hal ini, bahwa seorang dapat diangkat Menteri mana kala memiliki integritas yang baik. Proses penelusuran mengenai integritas seseorang sebaiknya melibatkan Lembaga yang terkait dengan pengukuran integritas tersebut, artinya presiden dalam menilai calon-calon Menteri dapat meminta bantuan dari KPK, PPATK, Ombudsman, Komnas HAM, dan Lembaga negara lain untuk mendapatkan informasi tentang integritas calon Menteri tersebut;

3. Proses pengisian Menteri perlu memunculkan iklim kompetisi yang selektif serta objektif. Gagasan yang sempat mucul pada saat perdebatan amandemen konstitusi di tahun 1999-2002 berkaitan dengan proses pengisian yang selektif dan kompetitif dapat dipertimbangkan. Bahwa presiden terpilih dapat membentuk tim kecil yang arahkan menyiapkan kabinet yang akan menunjang kerja-kerja presiden. Tim yang menyiapkan

${ }^{31}$ Ibid., hlm. 1053

${ }^{32}$ Gagasan tentang pengisian jabatan Menteri yang selektif mengarah pada mekanisme fit and proper test. Ibid., hlm. 1057

${ }^{33}$ Gagasan tentang pengisian yang kompetetif mengarah pada proses seleksi terbuka dimana setiap orang dapat diajukan dan mengajukan diri sebagai calon Menteri yang akan diangkat oleh presiden. Ibid., hlm. 1056 
cabinet ini dapat menerima usulan dari Lembaga manapun terkait dengan usulan Menteri yang dianggap layak, serta pada saat yang bersamaan juga dapat menerima nama-nama yang masuk melalui presiden atau bahkan berasal dari presiden. Tim ini kemudian melakukan tugasnya untuk menelusuri kepribadian, integritas calon Menteri dan bermitra dengan Lembaga negara baik KPK, PPATK dan Lembaga negara lainnya. Selain itu, tim ini dapat juga melakukan penelusuran kepekaran, keahlian dari namanama yang diseleksi menjadi Menteri. Hasil kerja dari tim ini kemudian menjadi pertimbangan utama oleh presiden dalam mengangkat seorang menjadi Menteri. Penciptaan kultur yang selektif dan kompetitif menjadi penting agar bias menghasilkan Menteri yang zaken yang dapat membantu presiden dalam menunaikan janji konstitusi.

\section{Penutup}

Kabinet yang diidentikan dengan cabinet zaken di era Soekarno meliputi cabinet Natsir, Wilopo dan Djuanda mengalami turbulansi politik yang akhirnya berujung pada usia cabinet ini yang tidak pernah bertahan dalam jangka waktu yang lama, hal itu tidak bias dipisahkan dari dukungan parlemen dan system pemerintahan yang bercorak parlementer ketika itu.

Tugas dan tanggung jawab yang berada dipundak Menteri tidaklah mudah, diperlukan kemampuan dan kompetensi untuk mengurusi bidang-bidang tertentu yang dibawahinya untuk kemudian menunjang kerja presiden dalam menunaikan janji konstitusi, oleh sebab itu maka diperlukan sebuah cabinet karya yang didasarkan pada kompetensi, keahlian dan profesionalitas Menteri yang diangkat. Saatnya menapaki jalan menuju zaken cabinet dengan mekanisme pengangkatan yang menciptakan kultur kompetisi, selektif dan objektif. Semua dapat mengusulkan orang-orang yang dianggap baik dan kompoten, tim kecil bentukan presiden yang akan menelusuri rekam jejak keahlian dan kepakaran serta integritas, dan hasilnya berbuah pada rekomendasi kepada presiden yang akan menentukan siapa-siapa saja Menteri yang akan membantunya mewujudkan pemerintahan yang berkualitas konstitusi, menunaikan janji konstitusi pada Pembukaan UUD NRI Tahun 1945, sekaligus juga menunaikan hak konstitusional warga negaranya.

\section{Daftar Pustaka}

\section{A. Buku}

Bachtiar Chamsyah, et.,al. 100 Tahun Mohammad Natsir, Berdamai Dengan Sejarah, Jakarta : Republika, 2008.

Mahkamah Konstitusi. Naskah Komprehensif Buku IV Jilid 1 Kekuasaan Pemerintahan Negara, Jakarta : Sekretariat Jenderal Mahkamah Konstitusi, 2010. 
M Dzulfikriddin. Natsir Dalam Sejarah Politik Indonesia : Peran dan Jasa Mohammad Natsir Dalam Dua Orde Indonesia, Bandung : Mizan Pustaka, 2010.

Novendri M. Nggilu. Hukum dan Teori Konstitusi (Perubahan Konstitusi yang Partisipatif dan Populis), Yogyakarta : UII Pres, 2014.

Remy Madinier, Islam and Politics in Indonesia : The Masyumi Party between Democracy and Integralism, Singapore : National University of Singapore, 2015.

Sardiman, Sejahrah : Program Ilmu Sosial, Jakarta : Quadra, 2006.

\section{B. ArtikelJurnal}

Febta Pratama Aman, "Kebijakan Politik Luar Negeri Indonesia Masa Kabinet Djuanda 1957-1957”, Jurnal Socia, Volume 10 Nomor 1 Mei 2013.

Retno Saraswati, "Desain Sistem Presidensial Yang Efektif”, Jurnal MMH, Jilid 41 Nomor 1 Januari 2012.

\section{Makalah}

Dadan Sutaryana, Postur Kabinet Jokowi, Momentum Mewujudkan Zaken Kabinet, Pusat Kajian Politik Universitas Indonesia, 12 Februari 2019.

Zainal Arifin Mochtar. Kabinet, Koalisi dan Sistem Presidensial, Rapat Kerja Nasional Asosiasi Pengajar Hukum Tata Negara dan Hukum Administrasi Negara, Gorontalo, 6 Juli 2019.

\section{PeraturanPerundang-undangan}

Konstitusi Republik Indonesia Serikat

Undang-Undang Dasar Sementara Republik Indonesia

Undang-Undang Dasar Negara Republik Indonesia Tahun 1945

Undang-Undang Nomor 39 Tahun 2002 tentang Kementerian Negara.

\section{E. Internet}

Indira Ardanareswari, Kabinet Zaken Bukan tanpa Preseden, Indonesia PernahMemilikinya. Tirto Id, 17 Mei 2019, https://tirto.id/kabinet-zaken-bukan-tanpa-preseden-indonesiapernah-memilikinya-dJfi, diakses pada 2 Agustus 2019. 
Volume 15, Nomor 1, Januari-Juni 2020

Materikita, Kabinet Pada Masa Demokrasi Liberal,https://materikita.com/kabinet-padamasa-demokrasi-liberal/, diakses pada 2 Agustus 2019.

https://id.wikipedia.org/wiki/Kabinet_Reformasi_Pembangunan,https://id.wikipedia.org/wiki/ Kabinet_Persatuan_Nasional, https://id.wikipedia.org/wiki/Kabinet_Gotong_Royong, https://id.wikipedia.org/wiki/Kabinet_Indonesia_Bersatu, https://id.wikipedia.org/wiki/Kabinet_Indonesia_Bersatu_II, https://id.wikipedia.org/wiki/Kabinet_Kerja, diakses pada 31 Juli 2019, pukul 20.35.

Dadan Sutaryana, Postur Kabinet Jokowi, Momentum Mewujudkan Zaken Kabinet, http://rri.co.id/serui/post/editorial/340/editorial/postur_kabinet_jokowi_momentum_ mewujudkan_zaken_kabinet.html, diakses pada 1 Agustus 2019, pukul 13.40. 